\title{
Achieving Sustainable Development Goals of Agenda 2030 in Bangladesh: the crossroad of the governance and performance
}

\author{
Md Mizanur Rahman
}

Bangladesh Public Administration Training Centre, Dhaka, Bangladesh

\begin{abstract}
Purpose - This paper aims to assess the performance of achieving the targets of Sustainable Development Goals (SDGs) by aligning with the recent initiatives taken by different ministries and divisions in Bangladesh. It also examines the institutional challenges associated with the implementation of SDGs.

Design/methodology/approach - Both primary and secondary data were analysed by applying different techniques. The initiatives taken by various ministries and divisions of Bangladesh resonated partially with 84 targets of SDGs.

Findings - Ambiguous mandates of different ministries and divisions have caused overlapping jurisdiction, followed by conflicts of interest and lack of cohesion. Inaccurate stakeholder analysis, data unavailability, lack of competency and accountability, and a top-down policy approach can be considered as the major institutional bottlenecks in achieving SDGs.

Originality/value - This paper advocates revising the map to incorporate the right stakeholders to avoid erroneous monitoring, evaluation, and finally, inaccurate reporting. The reallocation of business for ministries and divisions is warranted to abolish jurisdictional overlapping and conflict of interests and make SDGs friendly. Despite the COVID-19 pandemic recession, Bangladesh may be able to multiply its achievement with the same resources and efforts by addressing those drawbacks.
\end{abstract}

Keywords SDGs, Agenda 2030, Public governance, Overlapping jurisdictions, Top-down approach,

Bangladesh

Paper type Research paper

\section{Introduction}

The General Assembly of the United Nations embraced a "plan of action for people, planet and prosperity" known as the Agenda 2030 or Sustainable Development Goals (SDGs) (United Nations General Assembly, 2015, p. 1). It was an urgent call to transpose the world sustainably by taking lessons and experience from Millennium Development Goals (MDGs). The 2030 Agenda comprises 17 SDGs and 169 targets, representing a globally shared vision and a handsome to-do list, and an outline for the future generations (Morton et al., 2017). SDGs are an integrated and multifaceted view on development, which endorsed the necessity of collaboration and alignment among diverse stakeholders (Pradhan et al., 2017). United

(C) Md Mizanur Rahman. Published in Public Administration and Policy. Published by Emerald Publishing Limited. This article is published under the Creative Commons Attribution (CC BY 4.0) license. Anyone may reproduce, distribute, translate and create derivative works of this article (for both commercial and non-commercial purposes), subject to full attribution to the original publication and authors. The full terms of this license may be seen at http://creativecommons.org/licences/by/4.0/ legalcode

The project is funded by Bangladesh Public Administration Training Centre. The author is grateful to Dr. Alice Te, Managing Editor, for her guidance to improve the paper's quality. The role of the highly professional anonymous reviewers should be acknowledged. The author also expresses his gratitude to Dr. M Aslam Alam, Ex-Rector, and Md. Rakib Hossain, current Rector, Bangladesh Public Administration Training Centre, for their wholehearted support.
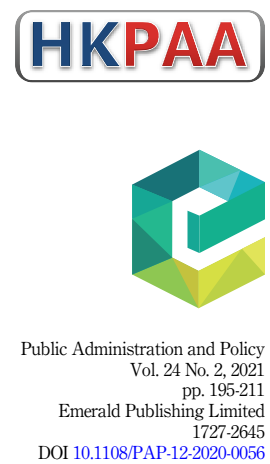
Nations Global Compact (2018) reported that organizations play a critical role in advancing

SDGs by adopting time-bound policies, actions, and innovative solutions for the challenges. However, various factors shape organizations' decisions to new issues and reporting of their obligations (Hahn and Kühnen, 2013).

Public governance is vital in successfully implementing Agenda 2030 for all countries as its role is more prominent in SDGs than in the MDGs (Morton et al., 2017). An accountable, effective, and inclusive public governance system is a standalone goal in the Agenda 2030. SDGs urge commitment from different levels, but public administration is everywhere. The public administration was called upon to adopt policies, strategies, or actions to achieve the goals (Turner and El-Jardali, 2017). Contradictorily, the implementation challenges are embedded with the public administration, particularly public service, considering scope, importance, limitation, and urgency.

However, various external and internal determinants may influence organizations' achievements to actualize sustainability (Hahn and Kühnen, 2013). This study contributes to the understanding of internal factors that affect the SDGs implementation from Bangladesh's perspective. Such an investigation will be useful to the policymakers who are responsible for designing public policies and strategies to expedite SDGs implementation and reporting in Bangladesh. This study may also help other stakeholders like civil society, donor agencies, academics, researchers, environmentalists, and Non-Government Organizations (NGOs).

An evaluation of national progress in implementing the SDGs is sensible to identify the gaps (Allen et al., 2018). Such study helps to analyze the degree to which pivotal implementation stages remain on the deck. Likewise, the assessment can highlight whether progress has been made in the initial planning stages. The study will help the policymakers to interconnect the linkages and trade-offs, and synergies between targets. The following section reviews the literature to build a analytical framework on Bangladesh's progress and challenges of SDGs associated with public governance.

\section{SDGs and Bangladesh}

Bangladesh made considerable progress in achieving MDGs despite geopolitical and environmental challenges (Datta and Rabbany, 2016). Like other countries, Bangladesh accepted SDGs. According to the SDG Index, Bangladesh is better positioned than some South Asian countries (Sachs et al, 2020). Progressively, a lot of initiatives ranging from institutionalization to localization were taken (Figure 1).

The country started the journey by mapping ministries/divisions as "lead", "co-lead", and "associate" based on their allocation of business (GED, 2016). The mapping methodology followed consultations with line ministries and divisions (Kati, 2020). The discussion with line experts, researchers, academicians, and other stakeholders remains unclear. Any wrong selection of stakeholders will result in improper reporting. In that case, monitoring and evaluation may not count many remarkable achievements. Therefore, the mapping and stakeholder selection accuracy needs to check-in as ten years to go more. Sabbih (2018) identified some challenges encountered by Bangladesh for implementing SDGs, such as proper alignment with national planning and policy processes and coordination. Availability of factual data, partnership, and stakeholders' active participation is highly challenging for the country. Weak institutional capacity, poor governance, and policy incoherence will affect more than resource mobilization (Sabbih, 2018). Ashraf et al. (2019) revealed that controlling overpopulation and managing unplanned urbanization are highly demanding. Coping with natural disasters and climate change, facilitating good governance, and narrowing regional disparity are the main challenges for Bangladesh's public sector. It was reported that at the implementation level, the business remains as usual under the bracket of SDGs due to a lack of transformation and internalization. More progress realizes in the "upstream" compared to 




Source: Adapted from Ministry of Planning (2020)

Figure 1. Government's efforts towards achieving SDGs

"downstream" (Khatun et al., 2020). Few studies identified several bureaucratic challenges in achieving SDGs underlining the corruption, politicization, polarization, inefficiency, and dominating behavior (Khatun et al., 2020; Sarker, 2017), but the root cause was rarely analyzed. Therefore, the study strived to identify the inherent institutional challenges that will affect SDGs implementation greatly.

Bangladesh needs around US\$928.48 billion for the effective implementation of SDGs (Ministry of Planning, 2020). However, it is not possible for the government alone to finance that amount. Therefore, it is essential to cement the coherence amongst different stakeholders (Hossen and Sultana, 2020).

The ministries and divisions are mandated by "Rules of Business 1996" which was revised on a few occasions, lastly in April 2017 (Government of the People's Republic of Bangladesh, 2017). The mandate of a public organization determines its frameworks, development, and outcomes. The business allocation parcels out decision-making authority from the public departments. Subsequently, jurisdictional overlapping, followed by the conflict of interest, emerges from this allocation (Gersen, 2007). In Bangladesh, many potential sectors have not flourished due to ambiguous mandates and jurisdictional overlapping among the public sectors (Hussain et al., 2017). Therefore, examining the suitability of the "Rule of Business" for SDG implementation is a prerequisite.

Voluntary National Review (VNR) 2020 has shown the target-wise progress by exploiting primary and secondary data from different sources, where VNR 2017 utilized only official data. Both VNRs could not incorporate some notable achievements. The "Citizen's Platform for SDGs, Bangladesh" (CPD) evaluated the performances of six goals based on the qualitative data (Khatun et al., 2020). Differently, the "Sustainable Development Solutions Network" (SDSN) assessed each 
PAP

24,2

198 country's goal-wise performance and trends based on few common indicators, which do not equally apply to each country. There is a mismatch between two reports that originated from different sources (Figure 2). Khatun et al. (2020) ranked the progress of six goals as SDG 4, 17, 8, 16,10 , and 13 based on respondents' perception. Despite insufficient data, the study showed that SDG 13 remains at the bottom. Contrarily, the rest of the world praises the way Bangladesh deals with climate adaptation and resilience. According to Sachs et al. (2020), SDG 12 surpassed the expectations considering only waste and emission per capita. Similarly, the performance of SDG 5 was downplayed, while SDG 3 and SDG 10 were heightened irrationally. Based on the vaccination coverage and HIV infection, the assessment of SDG 3 was misplaced. Hence, it has become indispensable to evaluate the institutional efforts in achieving SDGs targets empirically.

\section{Research methodology}

The study collected both primary and secondary data for the period from March to June 2020. The existing literature related to SDGs implementation challenges, institutional weakness, drawbacks of public policies, and legal framework were analysed to understand the broader picture of the data that was collected, and an analytical framework is developed. A stepwise systematical research approach was used for a better outcome (Figure 3).

\section{Identification of significant initiatives}

The study assessed the target wise progress by collecting secondary data from the annual reports under the financial years of 2015-2016, 2016-2017, 2017-2018, and 2018-2019 of 55 ministries/ divisions, and offices of Comptroller and Auditor General (CAG), Anti-corruption Commission (ACC), Information Commission (Infocom) and National Human Rights Commission (NHRC). Due to the annual reports' unavailability under the financial year 2019-2020, the annual performance agreements were critically analyzed to assess the commitments and the projected activities. Major SDGs centric laws, policies, strategic plans, and project documents were critically reviewed.

\section{Aligning with SDGs targets}

The vision, mission, and the course of the action plan of the identified projects, programs, public policies, and legal reforms were connected to SDGs targets. The number of associated targets per goal was enumerated.

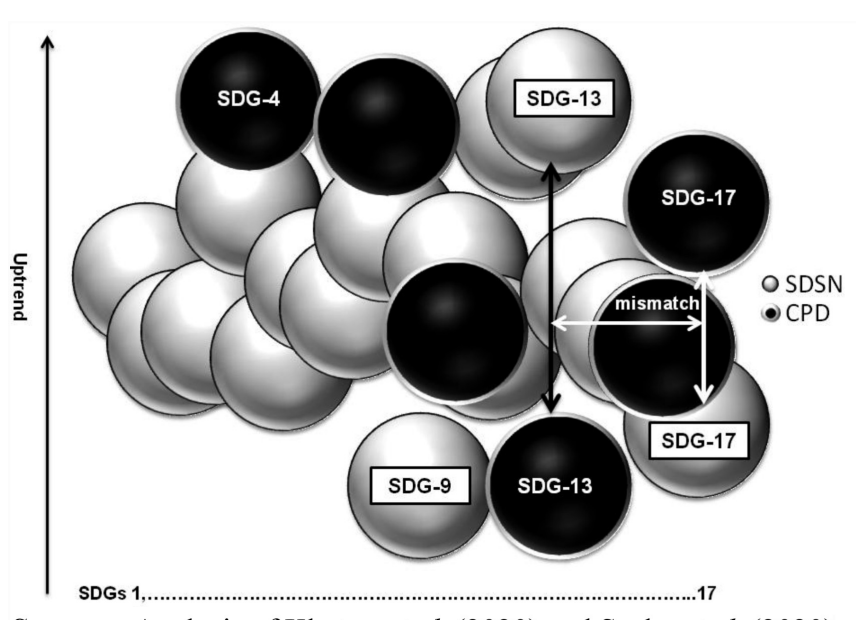

Sources: Analysis of Khatun et al. (2020) and Sachs et al. (2020)
Figure 2.

A comparative assessment of the performance by SDGs between these reports 




\section{Achieving SDGs of Agenda 2030}

Identification of inherent institutional drawbacks by interviewing retired civil bureaucrats

Compiling the solutions come from the interviewees

Figure 3.

The analytical framework

\section{Identification of sectoral challenges}

The study followed Key Informant Interviews technique as it helps the researchers to minimize the confusion in concluding. A total of 15 key informants were selected from a diverse group of line experts who have in-depth knowledge about social, economic, and environmental sustainability. They were classified into three major groups: social, economic, and environmental, and each group had five informants. Beforehand, a loosely structured checklist, including a list of issues to be discussed, was prepared. During the interviews, there was a free flow and exchanges of ideas and information, with discussions focused on national challenges.

\section{Case study}

A case study helps the researcher to gain a big picture idea of a complicated situation (Harrison et al., 2017). National Environment Policy 2018, which was formulated eying on SDGs implementation, was taken as a case to find out the shortcomings in the public policy. The allocation of business of ministries and divisions was scrutinized from the Rules of Business 1996. The business of the Ministry of Environment, Forest and Climate Change (MOEFCC) was critically analyzed to understand the appropriateness of the business allocation. The mapping of SDG 2 has been discussed to realize the accuracy of proper stakeholder selection. The case study followed a desktop data collection approach, and a few ambiguities were cleared up by the key informants.

\section{Identification of inherent institutional drawbacks}

For identification of the inherent institutional challenges, a number of five retired scholarbureaucrats, who have comprehensive ideas about public institutional weakness, policies, and SDGs. Nationally they are highly renowned and occupied very important positions in the government in the recent past. 
PAP

24,2

200

Compiling the solutions

Each interviewed key informants were humbly requested to recommend solutions to each problem they mentioned. All identified challenges and solutions were compiled. The solution was placed against the concerned challenges side by side.

\section{Content analysis}

The content analysis was done considering its uniqueness in that it supports both qualitative (Berg, 2009) and quantitative analysis (Krippendorf, 2004). The content analysis helps a researcher to analyze the themes, concepts, and interrelationships. The content analysis helps to transform a large number of texts into systematically organized and critical findings. The raw data from verbatim transcribed interviews can be coded and categorized quickly based on the themes. A further abstraction of data or condensation can be done at each step of the analysis (Erlingsson and Brysiewicz, 2017). At the outset, the collected data was coded into various categories and variables. De-contextualization, re-contextualization, categorization, and compilation were followed in this analysis.

\section{Results and discussion}

\section{Progress at a glance}

The initiatives taken by different ministries and divisions of Bangladesh are partially resonated with 84 targets of SDGs out of 169 (Table 1).

All ministries and divisions did not perform equally in terms of SDGs implementation. Similarly, all goals were not considered uniformly. Howbeit, most of the activities commenced before SDGs as routine works. Impressively, social safety net programs, micro-financing, and employment generation program for the poor help in curbing extreme and nationally defined poverty (Table 2).

The overseas employment sector emphasized increasing the remittance flow. The poverty in Bangladesh is declining at an average of 0.62 percent yearly. The extreme poverty dropped by roughly two-thirds in the last two decades, attributed to the expansion of readymade garment manufacturing and increased remittances (Iqbal and Pabon, 2018). Ministry of Agriculture (MOA), MOF, Ministry of Commerce (MOC), and MOHFW have taken various

\begin{tabular}{ll}
\hline Goal & Targets \\
\hline 1 & $1.1,1.2,1.3,1.4,1.5,1 . \mathrm{B}$ \\
2 & $2.1,2.2,2.3,2.4,2.5,2 . \mathrm{A}, 2 . \mathrm{B}, 2 . \mathrm{C}$ \\
3 & $3.1,3.2,3.3,3.6,3.7,3.8,3 . \mathrm{B}$ \\
4 & $4.1,4.3,4 . \mathrm{A}$ \\
5 & $5.1,5.2,5.3,5 . \mathrm{A}, 5 . \mathrm{B}$ \\
6 & $6.1,6.2,6.3,6.6$ \\
7 & $7.1,7 . \mathrm{A}, \mathrm{g.2}, 8.3,8.7,8.8,8.9,8.10$ \\
8 & $9.1,9.2,9.3,9.4,9 . \mathrm{C}$ \\
9 & $10.7,10 . \mathrm{B}$ \\
10 & $11.3,11.4,11.5,11.6,11 . \mathrm{B}$ \\
11 & $12.3,12.4$ \\
12 & $13.1,13.2,13.3$ \\
13 & $14.1,14.3,14.4,14 . \mathrm{B}$ \\
14 & $15.1,15.2,15.3,15.5,15.7$ \\
15 & $16.2,16.3,16.4,16.5,16.6,16.7,16.9,16 . \mathrm{A}$ \\
16 & $17.1,17.3,17.6,17.8,17.16,17.17,17.18$ \\
\hline 17 &
\end{tabular}




\begin{tabular}{|c|c|c|c|}
\hline Name & $\begin{array}{c}\text { Aligned } \\
\text { goals }\end{array}$ & Nodal ministry/division & Achieving \\
\hline Social safety net programs & 1,2 & Ministry of Social Welfare (MSW) & \\
\hline Employment generation program for the poor & 1,2 & $\begin{array}{l}\text { Ministry of Disaster Management and } \\
\text { Relief (MODMR) }\end{array}$ & \\
\hline Microfinance Project & $1,2,8$ & Financial Institutions Division (FID) & \\
\hline National Gene Bank Project & 2 & $\begin{array}{l}\text { Ministry of Science and Technology } \\
\text { (MOST) }\end{array}$ & 201 \\
\hline 4th Health, Population and Nutrition Sector & 3 & Ministry of Health and Family & \\
\hline Programme & & Welfare (MOHFW) & \\
\hline Higher Education Quality Enhancement Project & 4 & Ministry of Education (MOE) & \\
\hline Primary Education Development Program & 4 & $\begin{array}{l}\text { Ministry of Primary and Mass } \\
\text { Education (MOPME) }\end{array}$ & \\
\hline Secondary Education Development Program & 4 & MOE & \\
\hline $\begin{array}{l}\text { Strengthening women's ability for productive new } \\
\text { opportunities project }\end{array}$ & 4,8 & Local Government Division (LGD) & \\
\hline Women entrepreneurs' development program & 4,8 & $\begin{array}{l}\text { Ministry of Women and Children } \\
\text { Affairs (MOWCA) }\end{array}$ & \\
\hline My House My Farm Project & 1,8 & $\begin{array}{l}\text { Rural Development and Co-operatives } \\
\text { Division (RDCD) }\end{array}$ & \\
\hline She Power Project & 4 & $\begin{array}{l}\text { Information and Communication } \\
\text { Technology Division (ICTD) }\end{array}$ & \\
\hline Halda Protection Project & 6,15 & $\begin{array}{l}\text { Ministry of Water Resources } \\
\text { (MOWR) }\end{array}$ & \\
\hline Ruppur Nuclear Power Plant Project & 7 & $\begin{array}{l}\text { Ministry of Power, Energy and } \\
\text { Mineral Resources (MPEMR) }\end{array}$ & \\
\hline Rampal Power Plant Project & 7 & MPEMR & \\
\hline Child Sensitive Social Protection Project & 8 & MOWCA & \\
\hline Sugar Refinery at North Bengal Sugar Mills & 9 & Ministry of Industries (Moind) & \\
\hline Pro-poor Slums Integration Project & 11 & $\begin{array}{l}\text { Ministry of Housing and Public } \\
\text { Works (MOHPW) }\end{array}$ & \\
\hline Clean Air and Sustainable Environment project; & 11 & MOEFCC & \\
\hline Urban Building Safety Project & 11 & MOHPW & \\
\hline Household Silos & 12 & Ministry of Food (MOF) & \\
\hline $\begin{array}{l}\text { Integrating Community-based Adaptation into } \\
\text { Afforestation and Reforestation Programs" }\end{array}$ & 13,15 & MOEFCC & \\
\hline The Disaster Risk Management Enhancement Project & 13 & MODMR & \\
\hline Coastal Climate-Resilient Infrastructure Project & 13 & LGD & \\
\hline Sustainable Coastal and Marine Fisheries Project & 14 & $\begin{array}{l}\text { Ministry of Fisheries and Livestock } \\
\text { (MOFL) }\end{array}$ & \\
\hline Sustainable Forests and Livelihoods Project & $2,8,15$ & MOEFCC & 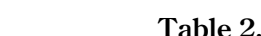 \\
\hline $\begin{array}{l}\text { National Strategy for Development of Statistics } \\
\text { Implementation Support Project }\end{array}$ & 17 & $\begin{array}{l}\text { Statistics and Informatics Division } \\
\text { (SID) }\end{array}$ & $\begin{array}{l}\text { Major SDGs' centric } \\
\text { projects and programs }\end{array}$ \\
\hline
\end{tabular}

initiatives to ensure food security through scaling down hunger and malnutrition. The Agriculture Orientation Index $(+0.5)$ is decent compared to that of other neighbors (FPMU, 2019).

Meanwhile, Bangladesh has made impressive progress in achieving SDG 3.2 by expanding the immunization program for newborn babies. Some programs and projects, remarkably Primary Education Development Program and Secondary Education Development Program, will attain quality education in primary and secondary levels. MOWCA has undertaken initiatives in line with the Convention on the Elimination of All Forms of Discrimination against Women, 1984, Beijing Platform for Action, and finally SDGs 5 (Table 3). Historically Bangladesh has been working hard to ensure gender parity and 


\begin{tabular}{|c|c|c|c|}
\hline \multirow[b]{2}{*}{$\begin{array}{l}\text { PAP } \\
24,2\end{array}$} & \multirow[b]{2}{*}{ Name } & \multirow[b]{2}{*}{$\begin{array}{l}\text { Aligned } \\
\text { goals }\end{array}$} & \multirow[b]{2}{*}{ Nodal Ministry } \\
\hline & & & \\
\hline \multirow{5}{*}{202} & National Environment Policy 2018 & All & \multirow{6}{*}{$\begin{array}{l}\text { MOEFCC } \\
\text { MOWCA } \\
\text { MOWCA } \\
\text { Ministry of Expatriates' Welfare and } \\
\text { Overseas Employment (MOEWOE) } \\
\text { MOEWOE } \\
\text { MODMR }\end{array}$} \\
\hline & Dowry Prohibition Act 2018 & SDG 5 & \\
\hline & Child Marriage Restraint Act 2017 & SDG 5 & \\
\hline & Expatriate Welfare and Overseas Employment & SDG 1,8 & \\
\hline & Policy 2016 & \multirow[b]{2}{*}{$\begin{array}{l}\text { SDG } 1,8 \\
\text { SDG } 1,2 \\
11,13\end{array}$} & \\
\hline & $\begin{array}{l}\text { Overseas Employment and Migrant Rules } 2017 \\
\text { National Plan for Disaster Management (2016-2020) }\end{array}$ & & \\
\hline & National Road Safety Action Plan & SDG 3 & \multirow{2}{*}{$\begin{array}{l}\text { Road Transport and Highways } \\
\text { Division (RTHD) } \\
\text { FID }\end{array}$} \\
\hline $\begin{array}{l}\text { Table 3. } \\
\text { List of SDGs' centric } \\
\text { laws, policies, and } \\
\text { strategic plans }\end{array}$ & $\begin{array}{l}\text { National Strategy for Prevention of Money } \\
\text { Laundering and Combating Financing of Terrorism } \\
\text { 2019-2021 }\end{array}$ & SDG 16 & \\
\hline
\end{tabular}

stands within the radius of this goal. Considering the global gender gap index and political empowerment, Bangladesh has secured the $50^{\text {th }}$ and $7^{\text {th }}$ positions in 2020 (WEF, 2020).

LGD has expanded safe drinking water national coverage and decreased the open defecation near zero. MPEMR has been implementing "Ruppur Nuclear Power Plant" and "Rampal Power Plant" to ensure long-term energy security. MOEWOE, ITCD, Ministry of Labour and Employment (MOLE); and FID have made considerable efforts to achieve higher levels of economic productivity. Bangladesh has counted 8.2 percent of GDP growth and 7.03 percent of GDP per capita growth in 2019 (The World Bank, 2020). The growth rate of real GDP per employed person increased to 5.85 percent in 2018-19 from 5.56 percent in 2017-18 (BBS, 2019). The industrial growth is ascending by undermining agricultural growth and maintaining a steady unemployment rate of around 4 percent (BBS, 2019). With international cooperation, few ministries have propelled infrastructure development. MOHPW has taken some projects, notably the Pro-poor Slums Integration Project, to improve the shelter and living conditions of the cities' low-income and informal settlements.

The Cabinet Division is working with the Annual Performance Agreement, Right to Information, Citizen Charter, National Integrity Strategy, and Grievance Redress System to develop accountable governance. Several ministries have taken initiatives to increase internal resources in achieving SDG 17. Notably, the Economic Relations Division (ERD) has expanded the horizons of international partnerships in resource collection.

As a newly graduated lower-middle-income country, Bangladesh has been making progress towards achieving SDGs. Bangladesh, one of the worst-hits of climate change and the most populous countries globally, cannot meet all ambitious targets of SDGs. It has made significant progress in achieving SDG 5, 7, 8, 17, 1, and 2. Oppositely, SDG 3, 10, 16, 14, 15, 12 , and 11 are lagged behind in terms of implementation. Based on the initiatives and the perceptions of the key informants, the study has made a zonation for the goals: comfort (greyish), intermediate (whitish), and discomfort (blackish) zone, which were ranked in descending order (Figure 4).

\section{Overarching challenges}

The COVID-19 has pounded the economy and affected the country's success in poverty reduction. It may lead to a spike in hunger and malnutrition (Raihan, 2020). Decreased land to human ratio intensifies the import's dependency, albeit crop production is higher than before (Roy et al., 2019). The agricultural market chain is distorted and controlled by intermediaries who make a multifold profit (Rahman et al., 2020). The cash crops' production shows a 

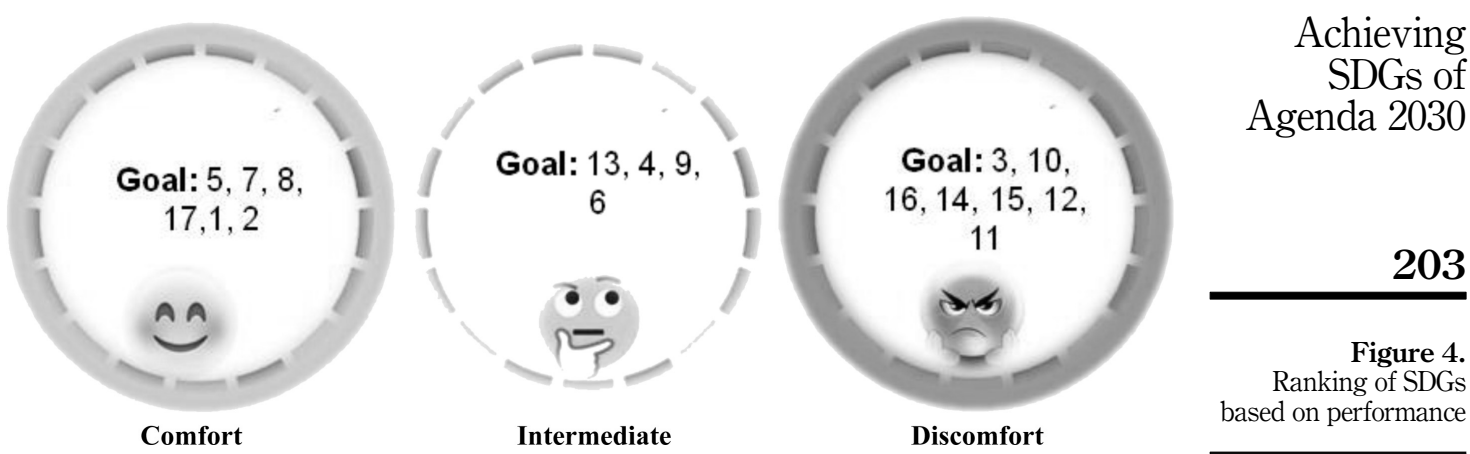

203

Figure 4.

Ranking of SDGs based on performance

declining trend due to extreme weather events (Rahman et al., 2017). Food contamination has become a custom, and the people have accepted this practice that poses a significant threat to the health of mass people. The COVID-19 tested enormous challenges in the fragile health sector. There is a lack of initiatives to ensure the enrolment of the left behind classes' children in primary school and lessen the disparities among different classes. The accessibility of disabled women to public facilities is unaccommodating (Akter and Rahman, 2018).

Any notable initiatives for protecting the periled freshwater ecosystems from further degradation and insulating the intensified river pollutions have not been perceived. Renewable energy contributes only 3 percent of total energy consumption (Uddin et al., 2019). The COVID-19 may jeopardize all achievements through squeezing job markets locally, nationally, and internationally. The informal labor (85 percent) and the extremely vulnerable class may be the hardest hit. Bangladesh is on the bottle rung in reducing income inequality. The Gini-coefficient and Palma ratio has been increasing (Bureau of Statistics, 2017), which may affect poverty reduction, followed by relative deprivation. The number of high net-worth individuals, notably ultra-rich people, increases sharply (Wealthx, 2019). Dhaka has obtained the second position globally in terms of air pollution (Arefin et al.,2017) while named the $3^{\text {rd }}$ worst city to live in in 2019 according to the global livability index.

To date, a ten-year-long framework for ensuring responsible consumption and cleaner production has not been prepared. The Public Procurement Rules 2008 is not accommodative with sustainable and green procurement. Incremental salinity propelled by brackish shrimp culture is considered a silent disaster for Bangladesh (Rahman, 2020). The country confronts sea-level rise, desertification, and the influx of climate refugees. Environmental justice could not be ensured for ordinary people (Rahman, 2021b). The declining fish stocks in the shallow waters occur due to commercial fishers' ascendancy in the estuaries and territorial waters by pushing out the artisanal fishers (Alam et al., 2021). The annual deforestation rate was 0.46 percent for the period 1930- 2015, maintaining an accelerated rate (Reddy et al., 2016), which resulted in perpetuating degradation of natural habitat. The plantation of exotic tree species like acacia and eucalyptus in the drought-prone North Bengal leads to green desert mayhem. Likewise, encroaching, poaching, destructive fishing by poisons and biological invasion change are the significant confrontations in life on land. There is a lack of notable initiatives to achieve 21 targets allied to Aichi Biodiversity Targets, which are unlikely to be achieved by 2020 .

Combating corruption, equal justice, and accountability of the law enforcers will be immensely demanding in ensuring inclusive governance. The Tax-GDP ratio is the lowest among the same countries (Hussain and Hossain, 2020). After the LDC graduation, the grant proportion is declining; contrarily, the loan is increasing. The tortoise-like implementation of the development projects downplays the utilization of foreign aid. Remittance inflow may be crippled by the pandemic COVID-19 recession. 
PAP

24,2

204
The rules of business

According to the respondents' perception, ambiguous mandates of the ministries/divisions, jurisdictional overlapping, the conflict of interests, inaccurate mapping, data unavailability, and lack of cohesion, competency, and accountability are considered the significant institutional weakness. In addition, the top-down approach is used in planning and policy formulation.

The ministries and divisions are mandated from the business allocation, legal, and policy framework. The key informants revealed that the business allocation and the legal framework contradict legitimizing authorities in many cases. Many segmented, scattered, and old laws legitimized many ministries to work on the same issue. They also confided that the Rules of Business 1996 allocated ambiguous and chaotic mandates on several occasions, which are not convenient for SDGs implementation. With the growing concerns about environmental degradation, Bangladesh formed the Ministry of Environment and Forests in 1989, earlier than the Rio Earth Summit of 1992. This ministry was renamed the Ministry of Environment, Forest and Climate Change in 2018 to tackle climate change. Still, any single words pointing this matter are absent in its business (Table 4).

The top-notch mandates are environment, ecology, and pollution control without any clarifications. Besides, the mandates do not pinpoint administrative boundary, type of ecology, and environmental realm. The pollution control applies to the pollution of the benthic zone to space. Thereupon, the jurisdictions and the line of authority are ill-defined, which causes a deadlock in establishing environmental governance and justice (Rahman., 2021b).

\section{Jurisdictional overlapping}

The key informants identified the significant areas where jurisdictional overlapping frequently occurs (Figure 5). It is revealed that social safety net, food security, infrastructure development, land and water management, tourism, pollution control, waste management, climate adaptation, biodiversity conservation, technical education, and control of illicit arms flow are intercepted by many public organizations simultaneously. The overlapping allows various ministries to adopt multiple safety net programs. The most chaotic condition exists in waste management, pollution control, and biodiversity conservation. The interceptions in social safety net programs serve the same beneficiary very often. Consequently, benefits go to the same house multiple times, which leads to increased inequality and a left-behind group.

Now and then, everybody's business emerges as nobody's business. The denial of the responsibilities comes to light in case of failure, conflict in the event of interests, and rivalry from exercising power. The conflict of interests among various departments leads to fragmented sector-by-sector and use-by-use management policies (Rahman, 2021a; Hussain et al., 2017).

\begin{tabular}{|c|c|c|}
\hline Ministry & Sub-ordinates & Allocated business \\
\hline MOEFCC & $\begin{array}{l}\text { - Department of Forest } \\
\text { - Department of Environment } \\
\text { - Bangladesh Forest Research } \\
\text { Institute } \\
\text { - Bangladesh Climate Change } \\
\text { Trust Fund } \\
\text { - Bangladesh National } \\
\text { - Berbarium } \\
\text { - Bangladesh Forest Industries } \\
\text { Development Corporation } \\
\text { Bangladesh Rubber Board }\end{array}$ & $\begin{array}{l}\text { - } \text { Environment and Ecology } \\
\text { - } \text { Matters relating to environmental pollution control } \\
\text { resources (Government and Private), forest inventory, } \\
\text { grading, and quality control of forest products } \\
\text { - Afforestation and regeneration of the forest, extraction } \\
\text { of forest products } \\
\text { - Tree plantation } \\
\text { - Research and training in Forestry } \\
\text { - Protection of wild birds and animals and establishment } \\
\text { of sanctuaries }\end{array}$ \\
\hline
\end{tabular}

Table 4.

Allocation of business for MOEFCC (a case) 



Notes: MLJPA is Ministry of Law, Justice and Parliamentary Affairs; MOCAT is Ministry of Civil Aviation and Tourism; MOD is Ministry of Defence; MOLWA is Ministry of Liberation War Affairs; MORA is Ministry of Religious Affairs; MOS is Ministry of Shipping; MOYS is Ministry of Youth and Sports

Figure 5.

Jurisdictional overlapping among ministries/divisions

It negatively affects institutional coordination, resulting in inadequate regulation. The respondents opined that the intercepted areas are robust which require multi departments for operationalizing the activities, but the number of players can be minimized. Appointing a focal point and developing an effective coordination mechanism can reduce the existing chaos. They also advocated for abolishing irrelevant interceptions to ensure that one's business is not everyone's. Business should be reallocated by amalgamating scattered and fragmented laws.

\section{Gaps in maps}

According to the earlier mentioned map, the lead, co-lead, and associate ministries/divisions initiated actions to fulfill the goals. The case of mapping SDG 2 shows how the closely related ministries were excluded, and the far-flung ministries were included (Table 5).

It is unimaginable to think about how food production is possible by ignoring MOWR. The denial of the role of the MOEFCC means the rejection of the food security of millions of vulnerable people depending on the Sundarbans' forest ecosystem services. They are directly dependent on the provisioning ecosystem services like honey, fishes, and crustaceans (Hussain et al., 2017). The absence of the MOST discounts the role of the National Institute of Biotechnology in increasing food productivity, developing resilient varieties, and establishing a national gene bank. The key informants opined that the mapping is erroneous due to deficiency of line experts' opinions, shortfall of internalization, and improper consultations. The inaccurate mapping may lead to faulty planning and subsequent haywire implementation, fragmented achievement, and scattered evaluation. Many notable achievements may be discounted, and unimportant attainments may be spotlighted 
Table 5.

Mapping of SDG 2 (a case)

\begin{tabular}{|c|c|c|c|c|c|}
\hline \multirow[b]{2}{*}{ Target } & \multirow[b]{2}{*}{ Existing Map } & \multicolumn{4}{|c|}{ Nature of stakeholders' engagement } \\
\hline & & Overrun & Downplayed & Far-flung & Absent \\
\hline 2.1 & $\begin{array}{l}\text { Lead: MOA; co-lead: } \\
\text { MOFL, MOF; } \\
\text { associates: MODMR, } \\
\text { Moind, MOWCA, } \\
\text { ICTD, MOE, MOPME, } \\
\text { SID, MOHFW (2.1.2); } \\
\text { Ministry of } \\
\text { Information (Moinf) } \\
\text { (2.1.2) }\end{array}$ & $\mathrm{x}$ & $\mathrm{x}$ & $\begin{array}{l}\text { Moind, } \\
\text { MOWCA, } \\
\text { ICTD, MOE, } \\
\text { MOPME, SID }\end{array}$ & $\begin{array}{l}\text { MOEFCC, MOST, } \\
\text { MOWR, Ministry of } \\
\text { Public Administration } \\
\text { (MOPA), Internal } \\
\text { Security Division (ISD), } \\
\text { MOHFW }\end{array}$ \\
\hline 2.2 & $\begin{array}{l}\text { Lead: MOHFW; co- } \\
\text { lead: MOF; associates: } \\
\text { MOA, MODMR, } \\
\text { MOFL, Moind, MSW, } \\
\text { MOWCA, Moinf, MOE, } \\
\text { MOPME, SID }\end{array}$ & $\begin{array}{l}\text { MOHFW, } \\
\text { MOF }\end{array}$ & $\begin{array}{l}\text { MOA, } \\
\text { MOFL }\end{array}$ & $\begin{array}{l}\text { MSW, Moind, } \\
\text { MOWCA, } \\
\text { ICTD, MOE, } \\
\text { MOPME, } \\
\text { Moinf, SID }\end{array}$ & $\begin{array}{l}\text { MOEFCC, MOST, } \\
\text { MOWR }\end{array}$ \\
\hline 2.3 & $\begin{array}{l}\text { Lead: MOA (2.3.1), } \\
\text { Moind (2.3.2); co-lead: } \\
\text { MOFL; associates: FID } \\
\text { (2.3.1.), LGD (2.3.1), } \\
\text { Ministry of Chittagong } \\
\text { Hill Tracts Affairs } \\
\text { (CHT) (2.3.1), MODMR } \\
\text { (2.3.1), MOF (2.3.1), } \\
\text { MOHFW (2.3.1), Moind } \\
\text { (2.3.1), Ministry of } \\
\text { Land (MOL) (2.3.1), } \\
\text { MSW (2.3.1), MOWCA } \\
\text { (2.3.1), MOEFCC (2.3.1), } \\
\text { SID (2.3.1) MOFL, MOE } \\
\text { (2.3.2), MOA (2.3.2) }\end{array}$ & Moind & MOEFCC & SID, MOHFW & $\begin{array}{l}\text { MOC, MOWR, MOST, } \\
\text { ICTD }\end{array}$ \\
\hline 2.4 & $\begin{array}{l}\text { Lead: MOA; associates: } \\
\text { MOEFCC, MOL, } \\
\text { MOWR, MODMR, } \\
\text { Moind, MOF, LGD, SID }\end{array}$ & $\mathrm{x}$ & $\mathrm{x}$ & Moind, SID & MOFL \\
\hline 2.5 & $\begin{array}{l}\text { Lead: MOA; co-lead: } \\
\text { MOFL; associates: } \\
\text { MOC, MOEFCC, } \\
\text { Ministry of Foreign } \\
\text { Affairs (MOFA) }\end{array}$ & $\mathrm{x}$ & MOEFCC & $\mathrm{x}$ & $\mathrm{x}$ \\
\hline 2.a & $\begin{array}{l}\text { Lead: MOA (2.a.1), } \\
\text { ERD (2.a.2); associates: } \\
\text { FID (2.a.1), LGD, } \\
\text { MOFL, MOFA (2.a.1), } \\
\text { General Economic } \\
\text { Division (GED) (2.a.1), } \\
\text { MOA (2.a.2) }\end{array}$ & $\mathrm{x}$ & $\mathrm{x}$ & $\mathrm{x}$ & $\begin{array}{l}\text { CHT, MOC, MODMR, } \\
\text { MOF, MOWR, MOST }\end{array}$ \\
\hline 2.b & $\begin{array}{l}\text { Lead: MOC (2.b.1), FD } \\
\text { (2.b.2), associates: FID } \\
\text { (2.b.1), MOA, } \\
\text { MOFA(2.b.1), } \\
\text { MOFL(2.b.1), MOC } \\
\text { (2.b.2) }\end{array}$ & $\mathrm{x}$ & $\mathrm{x}$ & $\mathrm{x}$ & MOEFCC \\
\hline 2.c & $\begin{array}{l}\text { Lead: MOC; co-lead: } \\
\text { MOF; associates: } \\
\text { Moinf, MOPA, SID }\end{array}$ & $\mathrm{x}$ & $\mathrm{x}$ & SID & ISD, ICTD \\
\hline
\end{tabular}

Nature of stakeholders' engagement MOWCA, MOPME, Moinf, SID MOWCA, Moinf, MOE, Moind (2.3.2); co-lead: MOFL; associates: FID (2.3.1.), LGD (2.3.1) inistry of Chittagong (CHT) (2.3.1), MODMR (2.3.1), MOF (2.3.1), MOHFW (2.3.1), Moind (2.3.1), Ministry of (2.3.2), MOA (2.3.2) MOEFCC, MOL Moind, MOF, LGD, SID MOFL - associates: MOC, MOEFCC, Ministry of Foreign Affairs (MOFA) ERD (2.a.2); associates: MOFL, MOFA (2.a.1), General Economic Division (GED) (2.a.1), Lead: MOC (2.b.1), FD (2.b.2), associates: FID .1), $\mathrm{MOA}$ MOFL(2.b.1), MOC MOF; associates: Moinf, MOPA, SID 
simultaneously. The defective mapping may hamper the fulfillment of cross-cutting issues at the cross juncture of SDGs. The respondents gave prominence to revise the map by taking all stakeholders' opinions, notably line experts, researchers, and academicians.

\section{Data availability}

The respondents apprehend that Bangladesh may face enormous challenges in measuring progress and monitoring and evaluation due to the unavailability and inadequacy of authentic data. Bangladesh has available data for 64 indicators, partially available for 58, while unavailable for 110 indicators (GED, 2018). Based on the data availability, SDG 1, 6, 9, $10,11,12,13,14,15$, and 16 fall behind. The maintenance of databases in public sectors is a crucial problem. Data manipulation and fabrication cast doubt about data's authenticity in some cases. Timely access and the gap in understanding are also significant problems. Standard methodological approaches and advanced technology are not used in data collection. Besides, data validation is rarely done. The National Data Coordination Committee should take crash programs to minimize the data gap.

\section{Coordination and integration}

The respondents divulged that the lack of coordination and integration is the actual drawback of the bureaucracy. Every ministry or division has a tendency to do everything alone, decoupling other stakeholders, which is the barrier in adopting the whole society approach. First of all, Bangladesh should develop a concrete institutional coordination and integration mechanism before taking further action. The lack of coordination between and among the players negatively impacted natural resources' sustainable use, including tourism and social welfare (Hussain et al., 2017). Bangladesh should bridge the gaps among public sectors, private sector, NGOs, community-based organizations and civil society to uphold the whole society approach.

\section{Competency and accountability}

The gaps in the maps array the scarcity of line experts and SDGs oriented workforce in the public service for internalization. The key informants identified several causal factors like the absence of career planning and path, polarization, politicization, wrong people in the wrong place, lack of stick and carrot approach, and rapid turnover. The respondents opined that these historical problems could not be solved overnight. A massive reform in public service ranging from recruitment to positioning will be required. It is essential to motivate them by placing the right people in the right place, providing incentives, preparing a career pool, imparting moral and SDGs-related training, and ensuring job satisfaction and performance appraisal.

\section{Top-down approach}

The respondents argued that the public policy, planning, and projects rarely bring positive outcomes in Bangladesh due to adopting the top-down approach in the formulaic stage. In most cases, political agenda and interventions, bureaucratic superiority and inertia, influences of the donors, inadequate research, institutional complexities, ambiguous guidelines, and the absence of line experts' opinions are reflected. The evidence and research-based problems are missing, even in the latest National Environment Policy 2018 (Table 6). It seems that before setting objectives, vision, mission, course of actions, and stakeholder selection, the problems were not defined based on research findings or experts' opinions. Instead, it took a general list of issues from a common understanding.

The respondents also stressed adopting a holistic approach in formulating policy, plan, and development projects. The opinions of all stakeholders, notably line experts, academicians, and researchers should be taken in the initial stage.
Achieving SDGs of Agenda 2030 
- The policy aims at achieving SDGs through environmental protection, pollution control, biodiversity conservation, and climate adaptation

- Identified 24 sectors/ areas and set a guideline for each

- The importance of research, ecotourism, biosafety, control of invasive species, coastal and marine ecosystem, 3R technology, and sustainable production and consumption has been added

- Underlined the commitments given in the accepted international conventions, protocols, treaties, codes, and

Table 6. Key features and gaps of National Environment Policy 2018 (a case) memorandums

- Taken almost all ministries and divisions as the stakeholders, where MOEFCC is the nodal ministry. Also, a national environment committee headed by the Prime Minister will advise from time to time
- Lack of reflection of research findings and line experts' opinions

- Did not specify the responsibilities for the stakeholders

- The coordination and integration mechanism is ambiguous.

- The problems originating from jurisdictional overlapping were not addressed

- The concept of environmental, water, land, forest and marine governance is absent

- There is no time frame, monitoring, and evaluation tools

\section{Conclusion}

Bangladesh, one of the fastest-growing economies in Asia, is nearing to achieve economic sustainability, albeit it faces the COVID pandemic recession like other countries. By learning the lessons from pandemic COVID-19, Bangladesh should prioritize SDG-3. Economic sustainability is not guaranteed until and unless social and environmental sustainability is achieved. Bangladesh could not show a hallmark sign in achieving ecological sustainability in terms of nature conservation. In particular, Article 18A was added to the Constitution of Bangladesh in 2011 to guarantee the protection and preservation of the environment and natural habitats for both present and future citizens. The incremental income inequality may jeopardize social sustainability. Lack of attention on the identified drawbacks will not only cripple the achievement but also downplay all initiatives as they are deeply rooted in regulatory frameworks. The lack of cohesion may result in fragmented and scattered progress. The country may be able to multiply its achievement by exploiting the same resources and efforts if the institutional weaknesses are adequately addressed.

Not only good but also competent, inclusive and accountable governance will be highly demanding to actualize SDGs. The study recommends minimizing jurisdictional overlapping for better integration and coordination. Revising the allocation of business of various important ministries eying on SDGs can solve this problem. The bottom-up approach and engagement of multi-stakeholders may help appropriate policymaking. Beforehand, stakeholder analysis will be highly warranted. Keeping data gap will be highly challenging to measure the progress. Accountable and good governance should be considered as the critical crosscutting issue. Comprehensive and rigorous research is advisable on different sectors separately. The country needs to develop an authentic national database so that future researchers can carry out indicator-based researches.

\section{References}

Akter, A. and Rahman, M. (2018), "Women with disabilities in Bangladesh: accessibility in the build environment”, Proshikhyan, A Journal of Training and Development, Vol. 26 No. 2, pp. 1-12.

Alam, S., Rahman, M.M. and Arif, A.A. (2021), "Challenges and opportunities in artisanal fisheries (Sonadia Island, Bangladesh): the role of legislative, policy and institutional frameworks", Ocean and Coastal Management, Vol. 201, pp. 1-12. 
Allen, C., Metternicht, G. and Wiedmann, T. (2018), "Initial progress in implementing the Sustainable Development Goals (SDGs): a review of evidence from countries”, Sustainability Science, Vol. 13 No. 5, pp. 1453-1467.

Arefin, M.A., Mallik, A. and Islam, M. (2017), "Air pollution and effect of pollution heightens in Dhaka city", International Journal of Advanced Engineering and Science, Vol. 6 No. 2, pp. 19-25.

Ashraf, M., Ullah, L., Shuvro, M.A. and Salma, U. (2019), "Transition from Millennium Development Goals (MDGs) to Sustainable Development Goals (SDGs): blueprint of Bangladesh for implementing the Sustainable Development Goals (SDGs) 2030", Medicine Today, Vol. 31 No. 1, pp. 46-59.

BBS (2019), Statistical Year Book 2019, Bangladesh Statistical Bureau, Dhaka.

Berg, B.L. (2009), Qualitative Research Methods for the Social Sciences, Allyn and Bacon, Boston.

Bureau of Statistics (2017), Household Income and Expenditure Survey 2016-2017, Statistics and Informatics Division, Bangladesh.

Datta, S.K. and Rabbany, S.H. (2016), "Sustainable development goals and Bangladesh: the role of parliament", International Journal of Development Research, Vol. 6 No. 7, pp. 8599-8606.

Erlingsson, C. and Brysiewicz, P. (2017), "A hands-on guide to doing content analysis", African Journal of Emergency Medicine, Vol. 7 No. 3, pp. 93-99.

Food Planning and Monitoring Unit (FPMU) (2019), Monitoring Report, The Bangladesh Second Country Investment Plan, Food Planning and Monitoring Unit, Bangladesh.

General Economics Division (GED) (2016), A Handbook: Mapping of Ministries by Targets in the Implementation of SDGs Aligning with $7^{\text {th }}$ Five Year Plan (2016-20), General Economics Division, Bangladesh.

General Economics Division (GED) (2018), Data Gap Analysis for Sustainable Development Goals (SDGs) Bangladesh Perspective, General Economics Division, Bangladesh.

Gersen, J. (2007), "Overlapping and underlapping jurisdiction in administrative law", Supreme Court Review, Vol. 2006 No. 1, pp. 201-247.

Government of the People's Republic of Bangladesh (2017), Rules of Business 1996 (Revised up to April 2017), Cabinet Division, Government of the People's Republic of Bangladesh.

Hahn, R. and Kühnen, M. (2013), "Determinants of sustainability reporting: a review of results, trends, theory, and opportunities in an expanding field of research", Journal of Cleaner Production, Vol. 59 No. 15, pp. 5-21.

Harrison, H., Birks, M., Franklin, R. and Mills, J. (2017), "Case study research: foundations and methodological orientations", Forum: Qualitative Social Research, Vol. 18 No. 1, pp. 1-17.

Hossen, Z. and Sultana, N. (2020), "Achieving SDGs: aligning private sector incentives with public goals", The Financial Express, available at: https://thefinancialexpress.com.bd/views/ achieving-sdgs-aligning-private-sector-incentives-with-public-goals-1579184979 (accessed 26 April 2021).

Hussain, G.M., Failler, P., Al Karim, A. and Alam, M.K. (2017), "Review on opportunities, constraints and challenges of blue economy development in Bangladesh", Journal of Fisheries and Life Sciences, Vol. 2 No. 1, pp. 45-57.

Hussain, Z. and Hossain, M. (2020), "A Review of Public Expenditures in Bangladesh: evidence on Sustainability and Cyclicality", in Hossain, M. (Ed.), Bangladesh's Macroeconomic Policy, Palgrave Macmillan, Singapore, pp. 163-196.

Iqbal, K. and Pabon, N.F. (2018), "Quality of growth in Bangladesh: some new evidence", Bangladesh Development Study, Vol. 41 No. 2, pp. 43-64.

Kati, C. (2020), "Integrate or separate: institutional design for the enforcement of Competition Law and Consumer Law", Amsterdam Centre for European Law and Governance Research Paper, University of Amsterdam, Netherlands, No. 2013-03, pp. 1-43.

Achieving SDGs of Agenda 2030 
PAP

24,2

Khatun, F., Bhattacharya, D., Rahman, M., Moazzem, K.G., Khan, T.I., Sabbih, M.A. and Saadat, S.Y. (2020), Four Years of SDGs in Bangladesh: Measuring Progress and Charting the Path Forward, Centre for Policy Dialogue and Citizen's Platform for SDGs, Bangladesh.

Krippendorf, K. (2004), Content Analysis: An Introduction to its Methodology, Sage, Beverly Hills, C.A. Ministry of Planning (2020), "Bangladesh Voluntary National Reviews 2020 - accelerated action and transformative pathways: realizing the decade of action and delivery for sustainable development", available at: https://mole.portal.gov.bd/sites/default/files/files/mole.portal.gov. bd/page/ac7088c7_a211_4905_9ff3_1e62af00c837/VNR_2020.pdf (accessed 16 October 2020).

Morton, S., David, P. and Squires, N. (2017), "Sustainable Development Goals (SDGs), and their implementation: a national global framework for health, development and equity needs a systems approach at every level”, British Medical Bulletin, Vol. 124 No. 1, pp. 81-90.

Pradhan, P., Costa, L., Diego, R., Wolfgang, L. and Kropp, J.P. (2017), "A systematic study of Sustainable Development Goal (SDG) interactions", Advancing Earth and Space Science, Vol. 5 No. 11, pp. 1169-1179.

Rahman, M.M. (2020), "Impact of increased salinity on the plant community of the Sundarbans Mangrove of Bangladesh", Community Ecology, Vol. 21, pp. 273-284.

Rahman, M.M. (2021a), "Achieving Sustainable Development Goals in Bangladesh: an organizational analysis”, Political Economy-Development: Environment eJournal, Vol. 9 No. 53, pp. 1-42.

Rahman, M.M. (2021b), "Can ordinary people seek environmental justice in Bangladesh? Analyzing through the lens of legal, policy, and institutional framework", Bangladesh Journal of Public Administration, Vol. 29 No. 2, pp. 15-34.

Rahman, M.M., Alam, M.A., Rahman, M.M., Mamun, M. and Alam, A. (2020), "Challenges of artisanal fishermen: a case study from Sonadia Island, Bangladesh", in Alam, M.A., Alam, F. and Begum, D. (Eds), Knowledge Management, Governance and Sustainable Development: Lessons and Insights from Developing Countries, Routledge, New Delhi, pp. 261-275.

Rahman, M.M., Islam, M.N., Hossain, M.R. and Ali, M.A. (2017), "Statistical association between temperature-rainfall and tea yield at Sylhet Malnicherra Tea Estate: an empirical analysis", The Jahangirnagar Review, Part II, Social Sciences, Vol. XLI, pp. 1-13.

Raihan, S. (2020), "COVID-19 and development challenges”, South Asian Network on Economic Modeling - Thinking aloud, Vol. 7 No. 5, pp. 1-4.

Reddy, C.S., Pasha, S.V., Jha, C.S., Diwakar, P.G. and Dadhwal, V.K. (2016), "Development of national database on long-term deforestation (1930-2014) in Bangladesh”, Global Planet Change, Vol. 139, pp. 173-182.

Roy, D., Dev, D.S. and Sheheli, S. (2019), "Food security in Bangladesh: insight from available literature", Journal of Nutrition and Food Security, Vol. 4 No. 1, pp. 13-18.

Sabbih, M.A. (2018), "Implementation challenges of SDGs country study: Bangladesh", Paper presented at Research-Policy meeting on Interpreting SDGs for South Asia: In search of a Regional Framework, Dhaka, Bangladesh, 20 November.

Sachs, J., Schmidt-Traub, G., Kroll, C., Lafortune, G., Fuller, G. and Woelm, F. (2020), Sustainable Development Report 2020, Cambridge University Press, Cambridge.

Sarker, M.N.I., Bingxin, Y., Sultana, A. and Shafiullah Prodhan, A.Z.M. (2017), "Problems and challenges of public administration in Bangladesh: pathway to sustainable development", International Journal of Public Administration and Policy Research, Vol. 3 No. 1, pp. 16-25.

The World Bank (2020), "World Bank national accounts data, and OECD National Accounts data files”, available at: https://data.worldbank.org/indicator/NY.GDP.MKTP.CD?locations=BD (accessed 26 October 2020).

Turner, T. and El-Jardali, F. (2017), "Building a bright, evidence-informed future: a conversation starter from the incoming editors", Health Research and Policy Systems, Vol. 15 No. 88 , pp. $1-3$. 
Uddin, M.N., Rahman, M.A., Mofijur, M., Taweekun, J., Techato, K. and Rasul, M.G. (2019), "Renewable energy in Bangladesh: status and prospects", Energy Procedia, Vol. 160, pp. 655-661.

United Nations General Assembly (2015), Transforming our World: The 2030 Agenda for Sustainable Development, United Nations, New York, N.Y.

Achieving SDGs of Agenda 2030

United Nations Global Compact (2018), "Global Goals for People and Planet”, available at: https:// www.unglobalcompact.org/sdgs/about (accessed 22 September 2020).

Wealthx (2019), "High Net Worth Handbook", available at: https:/d1tpu5nbeyfsm3.cloudfront.net/wpcontent/uploads/2019/01/Wealth-X_High-Net-Worth-Handbook-2019.pdf (accessed 29 May 2020).

World Economic Forum (WEF) (2020), "Global Gender Gap Report 2020”, available at: https://www. weforum.org/reports/gender-gap-2020-report-100-years-pay-equality (accessed 16 September 2020).

\begin{abstract}
About the author
Md. Mizanur Rahman has been working as Director (Research \& Development) at Bangladesh Public Administration Training Centre (BPATC), and he is also a Deputy Secretary to the Government of Bangladesh. He did his Bachelor and Master in Agricultural Sciences from Bangladesh Agricultural University, Mymensingh. He received his $\mathrm{PhD}$ on Forest Ecology from the University of Natural Resources and Life Sciences, Vienna, Austria. His areas of research interest are ecology, biodiversity conservation, natural dynamics, climatic-anthropogenic stressors, SDGs, governance and management. Md. Mizanur Rahman can be contacted at mizan_peroj@yahoo.com
\end{abstract}

For instructions on how to order reprints of this article, please visit our website:

www.emeraldgrouppublishing.com/licensing/reprints.htm

Or contact us for further details: permissions@emeraldinsight.com 